\title{
Melaka Streetscape Evolution: The six years journey
}

\author{
Shahrul Yani Said, Zalina Samadi \\ Faculty of Architecture, Planning And Surveying, \\ Universiti Teknologi MARA, Shah Alam, Malaysia \\ shahrulyani@salam.uitm.edu.my
}

\begin{abstract}
The study looks at the six years changes made to the streetscape of Melaka to adapt to the requirement of a better quality of life for the occupants. The different approach to regeneration scheme of Melaka could provide insight into modern demands for the city. The idea of integrating all the streets within the historic core area to form a synchronised pedestrian route system is plausible as it will help the users to experience the historic area as a whole may portray the trend of local economic growth and provide opportunities for improvement of the area.

Keywords: heritage; streetscape evolution; regeneration; Melaka

eISSN 2398-4279 @ 2018. The Authors. Published for AMER ABRA cE-Bs by e-International Publishing House, Ltd., UK. This is an open access article under the CC BY-NC-ND license (http://creativecommons.org/licenses/bync-nd/4.0/). Peer-review under responsibility of AMER (Association of Malaysian Environment-Behaviour Researchers), ABRA (Association of Behavioural Researchers on Asians) and cE-Bs (Centre for EnvironmentBehaviour Studies), Faculty of Architecture, Planning \& Surveying, Universiti Teknologi MARA, Malaysia.

https://doi.org/10.21834/ajqol.v3i11.125
\end{abstract}




\subsection{Introduction}

Places evolve through times due to the demand of the occupants. Changes took place to accommodate the need for a better life. The study looks at the changes made to the streetscape in Melaka to adapt to the requirement of a better quality of life for the occupants. Melaka a well-known historic area listed as World Heritage Site in 2008 with George Town in Penang. Both cities are known for their uniqueness as the melting pot of multicultural heritage from all over the world that set them apart from other places. The cities retain its distinctive architectural style of different periods of time. The area thrives with its rich cultural resources and has been the source for economic regeneration schemes. Almost (thirty percent) $30 \%$ of the land use in Melaka is for culturally related businesses and has become the centre of activity besides the wealth of culture and tradition can be seen throughout the city in the form of cultural built heritage and daily religious ritual of the residents.

The different approach to regeneration scheme of which was carried out in stages could provide insight into modern demands for the city. Theoretically, regeneration scheme focuses on introducing activities conducive to a place to offer opportunities for economic and social development of the area. Urban renewal, revitalization and redevelopment are part of the major urban regeneration scheme. Regeneration in context on Melaka, emphasis on redevelopment of areas which encompass modern development, while maintaining as much as possible of the historic fabric by local acts and policy (Said, S. Y et. al; 2014). The proposal for the economic improvement of the streets by the local authorities was aimed to add variety to the current local economy of the area, by providing opportunities for traditional small businesses.

Streets in Melaka are well-known for their individual characteristics. The idea of integrating of those streets within the historic core area as a heritage trail is to form a closelyknitted continuous circuit of pedestrian route system. The purpose for this integration is to enable tourists and visitors to navigate quickly from one street to another in exploring and grasping the existing urban space. It is plausible as it will help the users to experience the historic area as a whole - lively street shopping place as the business streets, the residential streets and the cultural streets. Comparison was made on the quality of streetscape through townscape evolution score marks from assessments carried out in 2010, 2013 and 2016, where the local authorities had made improvements to the area

\subsection{Literature Review}

Urban heritage streets revitalization in most heritage streets is not an impromptu situation since the urban physical setting is a result of the implementation of idea and policies based on thinking process from heritage committee supported by local authorities (Samadi, Z. et al., 2015). The process of "living up the almost dead of outdoor space" of space in between heritage streets requires heritage awareness and full participation of heritage shop owners. The creation of cultural shopping street is a "renewal of shopping style" that enlivens the streetscape. It is not enough just to conserve individual heritage shop lots, but the efforts need a pro-active resolution in taking care and regenerate of the outdoor activity and quality. On the other hand, an unattended space in between heritage buildings needs public attention 
rather than just left as no man's land (Samadi, Z. et al., 2012). There are positive activities for city citizen and visitors in occupying the unused spaces especially through on streets shopping, jamming and marketing.

The physical change with conservation approach supports the public space revitalization program has been designed to bring intercultural communities together (Ramlee, M. et al., 2015, Bagwell et.al, 2012). Urban public spaces with the renewal of physical property as valuable assets to the urban economy, social and environment should become part of the vision and mission of the historic city manager. A continuous effort in enhancing the physical and spiritual aspects of the outdoor ambience will support the urban renewal and regeneration process to ensure the heritage assets meets physical needs and trend rather than just symbolising the contemporary city. A proper revitalization tool for re-charging historic cities through renewal and regeneration process is necessary measures to be conducted within urban public space of the historic streets. It is hopeful will generate a sense of place, sense of belonging as well as a sense of community, by encouraging local activities and special events that are an integral part of urban heritage streets.

Urban regeneration schemes for Melaka have been carried out since the 1990s. The latest project was the result of the proposal outlined in the Conservation Management Plan (2011) submitted to UNESCO as part of the management plan for the WHS. The vision of the Plan is 'to generate a suitable development, a safe and calm city to live in, with the basic needs, preserve the historical heritage and consult the stakeholder...' (Majlis Bandaraya Melaka Bersejarah , 2010). It demonstrates the significant relationship between regeneration and heritage with the environment, social activities and the economy of the area. The research will evaluate the scheme carried out.

\subsection{Methodology}

A space syntax analysis conducted for this study to test the level of permeability of the area. The idea was to figure out the most suitable place for economic activity. The result produced (Figure 1) suggested a possibility for more financial inducement of activities in the area along Jalan Hang Jebat, Lorong Hang Jebat, Jalan Tukang Emas and Jalan Tukang Besi, which are within the high permeability area. Therefore, the proposed 'cultural shopping street' along Jalan Tukang Emas crossing to Jalan Hang Jebat or Jonker Walk is a good option, to attract tourists to walk to the area. The analysis also suggested a high permeability at Jalan Tun Tan Cheng Lock (Heeren Street), where most of the historic shop houses still exist. The conservation projects proposed for the area will help to improve the condition of the city and attract tourists to enjoy the heritage.

In many tourist-centred places, accessibility to the site and legibility is two most important elements to ease navigation. Therefore, townscape improvement works regarding the pedestrian area, streetscape condition and, foremost, the condition of the historic buildings should be taken into consideration in the conservation management plan for the area. Besides that, a good traffic management system that allows pedestrian circulation within the historic core would provide opportunities for traditional local businesses to grow. Insertions of budget hotel and heritage hotels offer active night activities such as outdoor dining along 
the historic streets promotes a safe and enjoyable walking activity.

This study is looking at the growth pattern of the area through assessments made to the streetscape. Therefore, the highest permeability streets were selected to see the physical changes in the score on the quality of the street from 2010 to 2016. For Melaka, the assessment was made for Jalan Tun Tan Cheng Lock (Heeren Street), Jalan Hang Jebat (Jonker Street) and Lorong Hang Jebat.

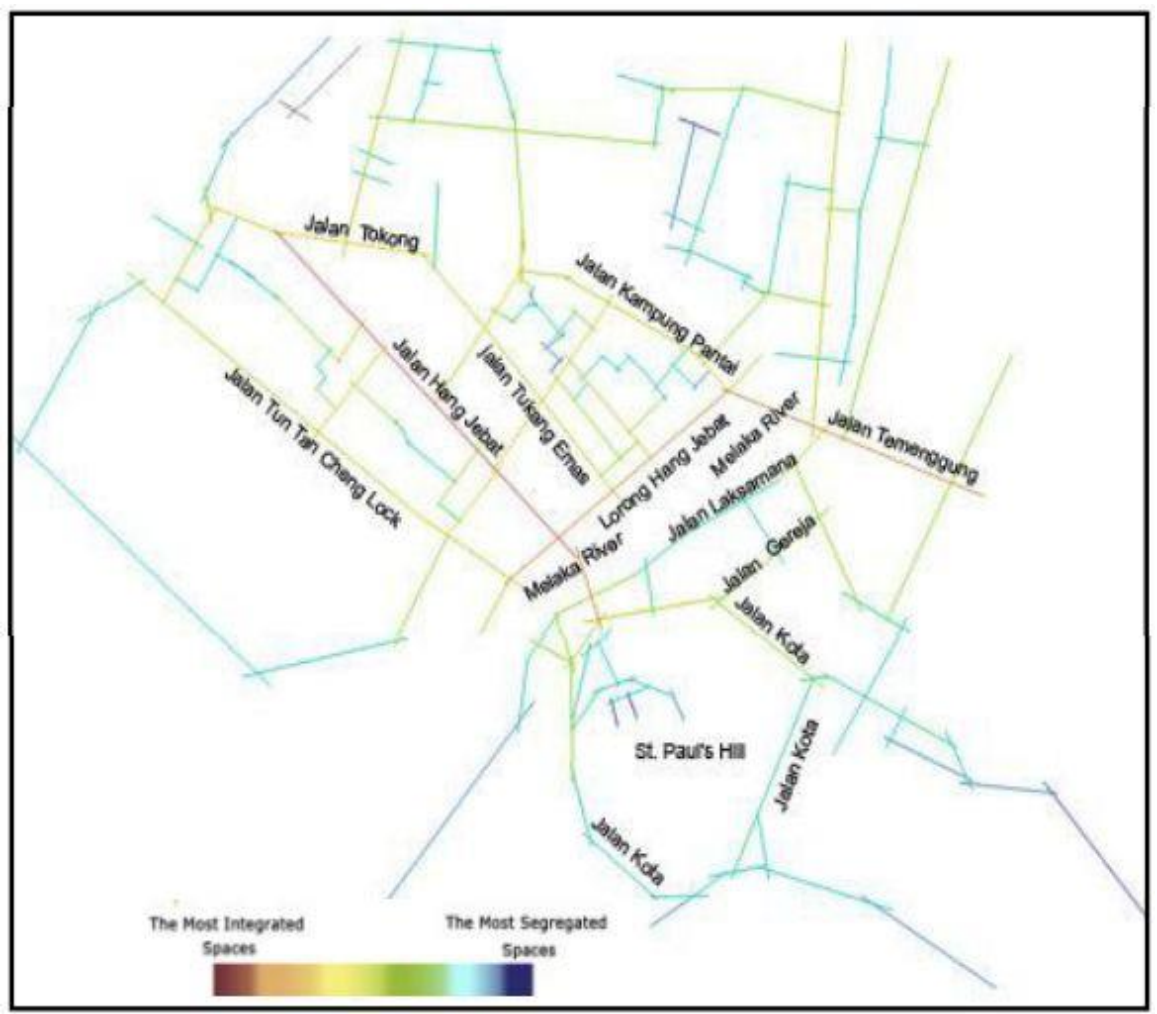

Figure 1: Space syntax analysis of Melaka

\subsection{Assessment of the quality of the street}

1.1. A townscape evaluation was carried out to assess the quality of the street. Physical changes took place to reflect the way of life of the occupants (Said, 2015). The study is a part of a larger on-going study on the regeneration of heritage area carried out by the researcher (Said, 2011). For this study, the focus is on selected street and how the changes took place reflects the demand for quality of life by the residents. The wealth of tangible and intangible heritage is sustained through the daily routine of the people in the historic premises 
in the case study areas. Businesses and trades have been the principal occupations in the area for years and are part of the social and cultural heritage of the area. The assessed area for this study is specific and analysis carried out using improved method from the previous survey. In this study fifteen (15) elements are assessed to give an overview of the quality of the street. Photographic evidence is included, and GPS locations for all assessment points were marked. Both methods will ensure the reliability of the data, where the point of assessment should remain the same for every evaluation.

Table 1: Elements of the assessment on the quality of the street

\begin{tabular}{|c|c|c|}
\hline & ements & Assessments \\
\hline 1 & Street scene & $\begin{array}{l}\text { Reflecting the street quality of the assessed area from the observation point } \\
\text { High: Environmentwhere the streetcondition is of a good quality and serves its purpose. } \\
\text { The clear interaction between pedestrian/users. } \\
\text { Low: Bad quality of streetscape with evidence of bad maintenance and vandalism. A low } \\
\text { number of pedestrian/ traffic activities. }\end{array}$ \\
\hline 2 & $\begin{array}{l}\text { State of the } \\
\text { building }\end{array}$ & $\begin{array}{l}\text { The condition of the bulding (in view/structural evidence). } \\
\text { High: The building is structurally sound and well-maintained. } \\
\text { Low: Clear evidence of dereliction and poor maintenance to the building. Evidence } \\
\text { suggested unsound structure. }\end{array}$ \\
\hline 3 & Trafic Flow & $\begin{array}{l}\text { Road traffic levels appropriate to the width and capacity of the road in view. Although } \\
\text { tailbacks might be expected in rush hours, frequentblockage or the use of a street as a 'rat } \\
\text { run' suggest inappropriate provision. } \\
\text { High: Regular and easy traffic flow appropriate to road and context. } \\
\text { Low: Conflicts between parking, passage and pedestrians. Hold ops out of rush hour. } \\
\text { Evidence of 'rat running.' }\end{array}$ \\
\hline 4 & $\begin{array}{l}\text { Accessibility } \\
\text { (point to point) }\end{array}$ & $\begin{array}{l}\text { An easy movement from one place to anofher (within the view). Poor streat mantenancewi } \\
\text { cause interruption to the route (pedestrian/vehicle). } \\
\text { High: Easy movement from one point to anofher. A good street fumitue and signagehelped } \\
\text { to guide the movement. } \\
\text { Low: Obstacles and poor mantenance of street fumiture and vegetafon interruptpedestrian } \\
\text { and vehicular movements }\end{array}$ \\
\hline 5 & $\begin{array}{l}\text { Personal } \\
\text { safety: traffic }\end{array}$ & $\begin{array}{l}\text { The view which suggests clear demarcation between safely moving trafific and pedestrian } \\
\text { spaces. Well marked crossing with adequate timing. } \\
\text { High: Environmentwhere pedestrian and traffic co-existwifhout confict or uns afe behaviour } \\
\text { on either part } \\
\text { Low: Evidence conflicts between traffic and pedestrians with frequent risk-taking or anxiety } \\
\text { on both parts. }\end{array}$ \\
\hline 6 & $\begin{array}{l}\text { Street furniture } \\
\text { quality }\end{array}$ & $\begin{array}{l}\text { Evidence of the quality and condition of street fumiture } \\
\text { High: a good condition of street fumiture, well-functioned, and relevant to the area } \\
\text { Low: street fumiture in bad condition: creates an obstruction to the area; being targets } \\
\text { for graffiti; redundant signs; posters; notworking as it should beaing in mind theconcern of } \\
\text { streets' users. }\end{array}$ \\
\hline 7 & $\begin{array}{l}\text { Road/Pedestri } \\
\text { an walkway } \\
\text { condition }\end{array}$ & $\begin{array}{l}\text { Street surfaces, paved areas in good, safe condition for the users. Appropriateness and } \\
\text { quality of materials, design and maintenance } \\
\text { High: sound and fit surfaces of good and in keepingmaterials, in a well-maintained condifon } \\
\text { for expected level of use } \\
\text { Low: Wom, patched, pot-holed road. }\end{array}$ \\
\hline 8 & $\begin{array}{l}\text { Infrastructure } \\
\text { (water/electrici } \\
\text { ty/refuse) }\end{array}$ & $\begin{array}{l}\text { Presence on public infrastructure and in an appropriate condition to serve the area/public } \\
\text { needs. Evidence of good management of public infrastructure regarding waste, water and } \\
\text { energy management, }\end{array}$ \\
\hline
\end{tabular}




\subsection{Findings and Discussions}

The fifteen elements above provide a quantitative value to the streetscape assessed. Seventeen (17) assessed points were used to score the environmental quality of the street (Figure 2). The points were the same standing point used in 2010 and 2013 assessments identified by the photos captured during the previous fieldworks. All the points were named according to the streets where the assessments were carried out (Table 2).

Table 2: Assessments points

\begin{tabular}{|l|c|c|}
\hline Street & Abbreviation & No of points \\
\hline Heeren Street (Jalan Tun Tan Cheng Lock) & HS & 7 \\
\hline Jonker Street (Jalan Hang Jebat) & JS & 7 \\
\hline Lorong Hang Jebat & LJ & 3 \\
\hline & Total & 17 \\
\hline
\end{tabular}

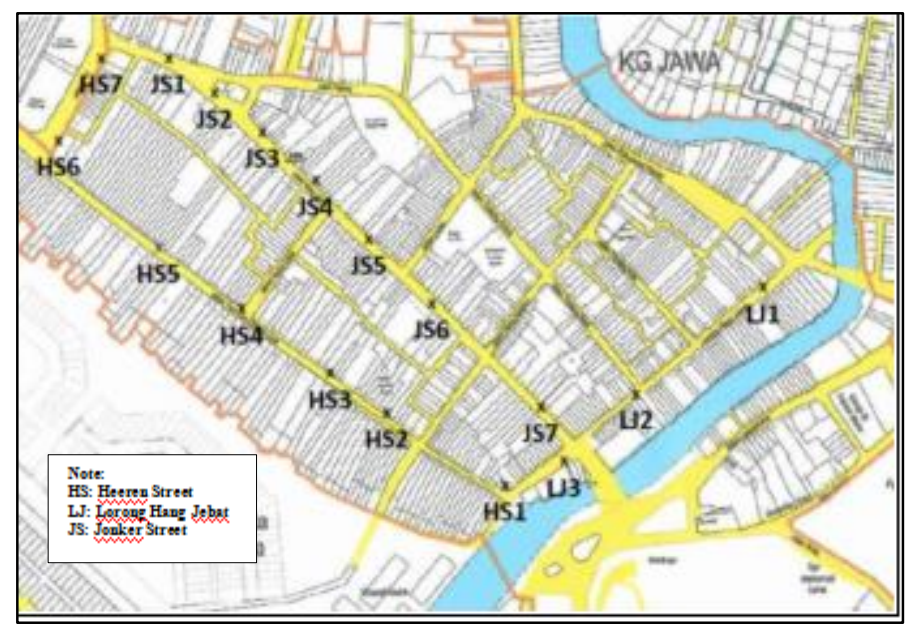

Figure 2: Assessment points for Environmental Quality and Streetscape

\subsection{The Findings}

From the assessment made since 2010, many changes were detected. Most of the streets were much improved than before. New economic activities were introduced to the area and had attracted a number of visitors to the place. Moreover, since an internationally well-known brand, the Hard Rock Café began its operation in 2013, a lot of improvement to the surrounding streetscape could be seen. The restaurant was located at the very beginning of Lorong Hang Jebat, where the entrance to this unique heritage area is located, hence a pull to tourists. 
The results of the observations made during the field study show that conservation, urban renewal and revitalization schemes carried out since the mid-1980s have contributed to the economic growth of the area. Besides that, some urban regeneration phases done by the local authorities helped to uplift most of the historic buildings in the area slowly. According to Pendlebury et. al (2004) 'the quality of historic environments as part of place-marketing/cityimage initiatives became increasingly evidence, as urban areas sought to use cultural policy as a strategy of urban regeneration'(Pendlebury et al., 2004: p19). Furthermore, the conservation of historic buildings as a flagship scheme in development projects is a good strategy for urban regeneration (Pendlebury et al., 2004: p19).

\subsection{Data Analysis}

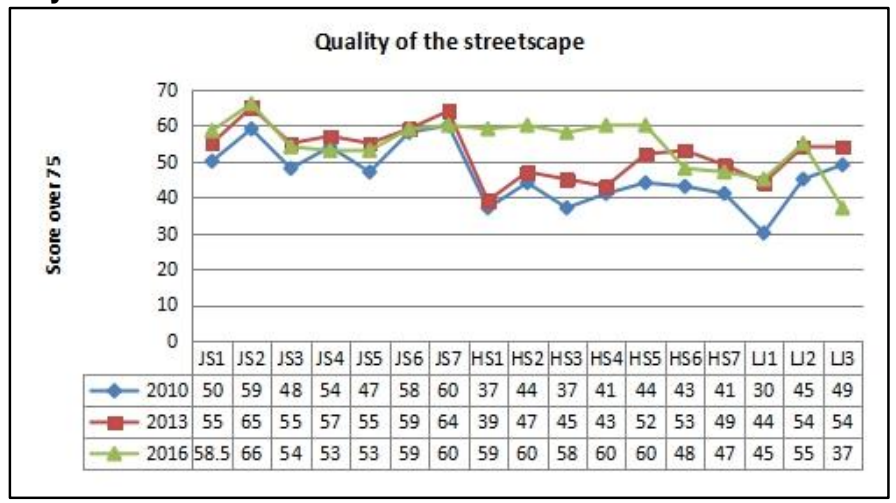

Figure 3: The result of the townscape assessment evaluation

The result from the assessment (Figure 3 ) indicates that significant improvement to the streetscape could be seen along Heeren Street (Jalan Tun Tan Cheng Lock) (HS1-HS6). This street consists of Dutch style shop houses dated from the 1700s. Most of the buildings are for residential buildings, however, most of the buildings currently being converted to boutique hotels. During the first assessment in 2010, some shophouses in Heeren Street are undergoing conservation work (Figure 4a). The conservation work is under Phase 1 of three phases of regeneration of the area by the local authority. Phase 1 was carried out from 2009 to 2010 while Phase 2 from 2011 to 2013 and Phase 3 on 2014 to 2015. The authority has allocated RM 200, 000.00 to this programme. The regeneration programme is carried out 'to promote the usage of the buildings as residential premises and to maintain traditional activities' (Melaka. Majlis Bandaraya Melaka Bersejarah, 2010, p4.28).

In the second assessment carried out in 2013, conservation work has not completed yet, which led to similar scores on the quality of the streetscape. However, the recent visit in January 2016 shows a major improvement to the streetscape, where most of the conservation work has completed (Figure $4 b$ ), thus the better score. However, there is also a fluctuation of townscape quality score at the very end of Lorong Hang Jebat because of recent conservation project carried out in the area (Figure 5). The restricted view caused 
lower score for accessibility, vitality, safety and coherence.
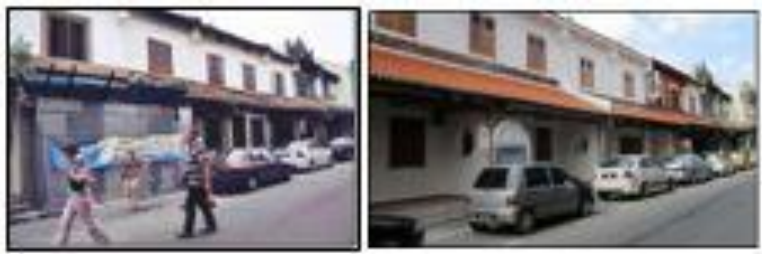

Figure 4 a \& b: Heeren Street (HS4) in 2010 (left) and 2016 (right)
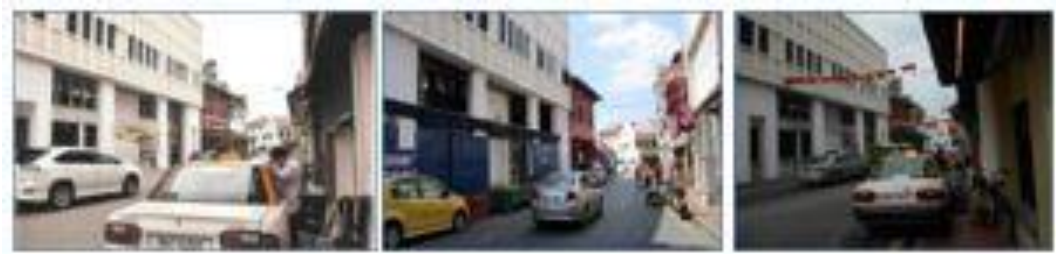

Figure 5: Changes to Lorong Hang Jebat (LJ3) 2010 (left) 2013 (middle) 2016(right)
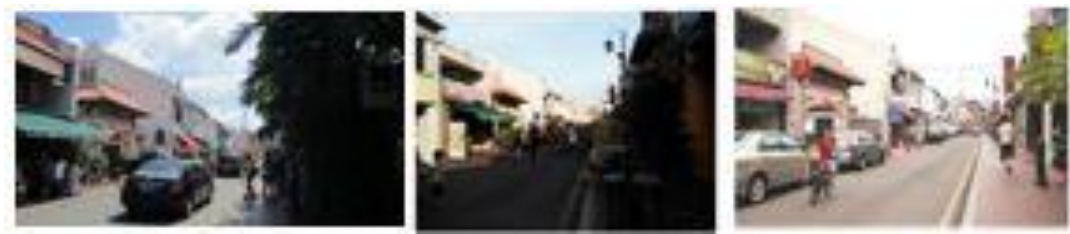

Figure 6: Changes in Jonker Street (LJ4) 2010 (left) 2013 (middle) 2016(right)

The assessment made during the fieldwork indicated that the townscape quality of the peripheral area of the heritage core zone is at the highest for townscape quality and streetscape assessment. The results showed that, although most of the area near the edge of the core area had a good quality of townscape, there were areas that need to be improved to ensure the overall condition of the townscape quality for Melaka at its very best. Proper conservation and innovative works to the historic buildings and good quality of streetscape can add value to the buildings and its area and should inspire economic regeneration in the area and help to sustain the tourism industry. Besides that, an improved streetscape has triggered many economic opportunities to the area in the form of business and hospitality services. The scheme has also provided employment opportunity and offers a better quality of life for the users

\subsection{Conclusion}

The surveys carried out in Melaka help in providing an overall picture of the state of conservation and regeneration of the historic city. The results of the key indicators show that 
the conservation of the historic buildings in Melaka aims to regenerate and revitalise the area economically and culturally. The active participation of the stakeholders in ensuring the sustainability of the heritage could be seen through their willingness to support and plan for the regeneration of the area.

This study has proved that over the five years period of evaluation, the outdoor public spaces have improved due to conservation efforts and outdoor space enhancement. The evolution of quality of outdoor space and physical characteristics provide an important contextual cue for Melaka residents and tourists as the majority users that the outdoor space has attracted local and global attention. The street shopping activity that supports economic vibrancy within the built cultural heritage is no longer shop owners issues, but it creates an influx of tourism industry. The physical change towards the ambience of the streets has triggered the adjacent neighbourhood to enhance façade, outdoor space public space and more visitors come in which this scenario contribute to the urban development in the perspective of tourism development and lively of the city. The physical change, of course, is part of the success attributes to stimulate visually public perception in experiencing outdoor spaces and elevate city image and improve the vitality of the city. It seems that public space has provided excellent facilities and services to the users to enjoy their urban lifestyle. Hopefully, the outcome of this study will elevate the awareness amongst local public authority on the importance of conservation initiatives and will increase future provisions to make a significant change towards the economic success of historic streets.

\section{Acknowledgement}

The authors would like to acknowledge Universiti Teknologi MARA (UiTM) for facilitating the research. This research is a longitudinal study on the quality of townscape of historic areas in Malaysia carried out by the researcher for a doctoral thesis completed in 2011 and continued with research grant scheme (600-RMI/DANA 5/3/PSI (300/2013).

\section{References}

Bagwell, S., Evans, G., Witting, A., \& Worpole, K. (2012). Public space management. London Metropolitan University.

Carmona, M., Heath, T., Oc, T. \& Tiesdell, S. (2003). Public Places - Urban Spaces: The Dimensions of Urban Design. Oxford: Architectural Press.

Isidori, F. (2015). A structural project: redevelopment of the historic center of Wuhu. Frontiers of Architectural Research, Retrieved from http://dx.doi.org/10.1016/j.foar.2015.01.001

Majlis Bandaraya Melaka Bersejarah (2010). Special Area Plan: Conservation Area Management Plan Of Melaka Historical City. Melaka: Majlis Bandaraya Melaka Bersejarah.

Pendlebury, J., Townshend, T. and Gilroy, R. (2004). The Conservation of English Cultural Built Heritage: A force for social inclusion? International Journal of Heritage Studies 10 (1), pp.11-31. 
Qamaruzzaman, H., Samadi, Z. \& Farhana, N. (2012). The Opportunity for Leftover Space: Activity Under Flyovers of Kuala Lumpur. Science Direct. Procedia - Social and Environmental Science. Volume 35 (2012).

Reeve, A. (2008). Evaluating the THI. Townscape Heritage Initiative Conference. Machester

Ramlee, M. et al. (2015). Revitalization or Urban Public Place in George Town: An Overview. Procedia Environmental Behavioural Studies. AcE-Ebs 2015. Tehran, Iran.

Ramlee, M. et al. (2015).Successful Characteristic of Public PlacesThrough Users Perception. ASEAN-Turkey ASLI (Asean Serial Landmark International). Conference on the Quality of Life 2015. ABRA International Conference on Quality of Life; AiQOL 2015. Izmir, Turkey

Mohd Yunus, R., Samadi, Z. \& Omar, D. (2015). Making of " Great Heritage Streets". Science Direct, Procedia of Social and Environmental Behavioural Science. 168 (2015) 365-372.

Said, S. Y., Aksah, H. \& Ismail, E.D (2012). Heritage conservation and regeneration of historic areas in Malaysia. Social and Behavioral Sciences, 105(0), 418-428.

Said, S. Y., Syed Zubir, \& S. S., Rahmat, M. N. (2014). Measuring physical changes in an urban regeneration scheme. In Marchettini, N., Brebbia, C. A., Pulselli R. \& Bastianoni, S. (Eds.), The Sustainable IX: Urban Regeneration and Sustainability, 1, 10, WIT Press.

Samadi, Z, Omar, D \& Mohd Yunus, R. (2012). Evaluating Revitalising Toolkit Towards Quality Heritage Streets Establishment. Science Direct. Procedia of Social and Environmental Behavioural Studies. Volume 35 (2012). 637 644

Walliman, N. (2006). Social Research Methods. London: SAGE 